\title{
Paideusis
}

\section{In Memory: Harry Samuel Broudy 1905-1998}

\section{Michael Jackson}

Volume 12, Number 1, 1998

URI: https://id.erudit.org/iderudit/1073091ar

DOI: https://doi.org/10.7202/1073091ar

See table of contents

Publisher(s)

Canadian Philosophy of Education Society

ISSN

0838-4517 (print)

1916-0348 (digital)

Explore this journal

Cite this article

Jackson, M. (1998). In Memory: Harry Samuel Broudy 1905-1998. Paideusis,

12(1), 3-3. https://doi.org/10.7202/1073091ar

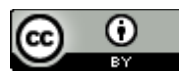

This document is protected by copyright law. Use of the services of Erudit (including reproduction) is subject to its terms and conditions, which can be viewed online.

https://apropos.erudit.org/en/users/policy-on-use/
This article is disseminated and preserved by Érudit.

Érudit is a non-profit inter-university consortium of the Université de Montréal, Université Laval, and the Université du Québec à Montréal. Its mission is to promote and disseminate research.

https://www.erudit.org/en/ 


\section{In Memory \\ Harry Samuel Broudy \\ 1905-1998}

Scarcely a month before his ninety-third birthday, educational foundations and, in particular, philosophy of education lost one of its great figures of the twentieth century. Harry Broudy was born in Poland in 1905 but moved to the United States in 1912. He combined his university studies (A.B., Boston, 1929; M.A., Ph.D. Harvard, 1933, 1935) with an early carcer in journalism. He was appointed to the Massachusetts Department of Education (1936-37) and went on to teach at North Adams State Teachers College (1937-1949), Framingham State Teachers College (1949-1957), and the University of Illinois (1957-1974) where, on retirement, he was named emeritus professor.

On retiring, he became the first Visiting Distinguished Professor in the Faculty of Education at Memorial University of Newfoundland (1974) and, in subsequent years, was invited to California State University Los Angeles (1978), Ball State University (1982), Ohio State University (1983), and the University of Arizona (1986).

A noted public speaker and frequent guest lecturer, member of many different boards, recipient of three honorary doctorates, author of numerous articles, and author and editor of a dozen books, his courage, wit, and critical insight made him a force to be reckoned with in any discussion of educational policy. One thinks of his demolition of competency-based approaches to teacher education and his comments on the re-orientation of our own field towards policy studies. But it was his support of younger scholars and readiness to listen to what others wanted to say that endeared him to later generations long after his own position-classical realism-and the insights and approach to philosophy it represented had ceased to be fashionable. Our field-indeed, the entire domain of education-has lost the wisdom and guidance of a thoughtful gentleman and a kindly scholar. 